\title{
The effect of enzymes on release of trace elements in feedstuffs based on in vitro digestion model for monogastric livestock
}

\author{
Xiaonan Yu, Jianan Han, Haiyun Li, Yiwei Zhang and Jie Feng
}

\begin{abstract}
Background: This experiment was conducted to study the effect of different feed enzymes (phytase, xylanase, $\beta$-glucanase) on release rate of trace elements ( $\mathrm{Fe}, \mathrm{Cu}, \mathrm{Mn}$ and $\mathrm{Zn}$ ) in 6 commonly used feedstuffs (corn, wheat, barley, soybean meal, wheat bran, wheat middlings) by using an in vitro model, simulating the digestive processes in stomach for $2 \mathrm{~h}$ and then in small intestine for $6 \mathrm{~h}$ at $39^{\circ} \mathrm{C}$.

Results: Phytase raised $(P<0.05)$ the release rate of $\mathrm{Cu}$ and $\mathrm{Zn}$ in corn, $\mathrm{Cu}, \mathrm{Zn}$ and $\mathrm{Mn}$ in wheat, $\mathrm{Cu}$ in barley, $\mathrm{Cu}$, $\mathrm{Zn}$ and $\mathrm{Mn}$ in soybean meal, $\mathrm{Zn}$, Fe in wheat bran and $\mathrm{Zn}, \mathrm{Fe}, \mathrm{Mn}$ in wheat middlings. The release rate of various trace elements in feedstuffs was increased after xylanase addition. Compared with the control group, the release rate of soluble $\mathrm{Cu}$ in corn, wheat, barley and soybean meal, soluble $\mathrm{Zn}$ in corn, wheat and wheat middlings and soluble of $\mathrm{Mn}$ in corn, wheat, barley and wheat bran increased $(P<0.05)$ after xylanase treatment. After the treatment of $\beta$-glucanase, the release rate of soluble $\mathrm{Cu}$ in corn, wheat and wheat bran, soluble Fe in barley, soybean meal and wheat bran and soluble $\mathrm{Mn}$ in corn and wheat bran all increased $(P<0.05)$ compared with the control group. In each feedstuff, after corresponding enzyme treatment, the contents of phytic acid, xylan and $\beta$-glucan were significantly lower than those of the control group $(P<0.05)$.
\end{abstract}

Conclusions: Results showed that bound trace elements in feedstuffs can be released by feed enzymes. It may be necessary to take the trace elements in feedstuffs into account in the actual feed preparation including feed enzymes.

Keywords: Feedstuffs, Feed enzymes, In vitro model, Release rate, Trace elements

\section{Background}

Trace elements are essential nutrients for animal growth. They play critical roles in various biochemical processes and functions and consequently, are generally supplemented as inorganic forms in the livestock diets [1]. The bioavailability of inorganic trace elements such as $\mathrm{Cu}$ and $\mathrm{Zn}$ is low, about $7 \% \sim 15 \%$ and $5 \% \sim 10 \%$, respectively, in monogastric animals, which result in a large amount of trace elements (more than 95\%) being excreted in feces and urine [2-4] to eventually reach ground water and soil. After years of manure spreading for agriculture purposes, trace elements may accumulate in soil at toxic levels, the feed and food plants grown on the metal-contaminated

\footnotetext{
* Correspondence: fengj@zju.edu.cn

Key Laboratory of Animal Nutrition \& Feed Science, College of Animal Science, Zhejiang University, Hangzhou 310012, People's Republic of China
}

soil will also be polluted, thus bring potential threats to animals and people [4].

Feedstuffs contain a certain amount of trace elements, while often be ignored when configured in the actual feed formulation. This may result from the exist of antinutritional factors such as phytic acid and non-starch polysaccharides in feedstuffs, which affect the bioavailability of the trace elements [5-7]. Therefore, study on improving the release rate of trace elements in feedstuffs is of great significance on reducing the supplementation of exogenous trace elements in feed and the emission of them in animals' feces or urine, thus saving feed costs and protecting environment.

Recently enzyme preparations such as phytase and NSP enzymes have been widely applied in feed industry to hydrolyze corresponding anti-nutritional factors and then improve nutrient digestion and absorption efficiency, for instance, the application of phytase could 
improve the utilization rate of $\mathrm{Ca}$ and $\mathrm{P}$ [8-11]. NSP enzyme such as xylanase and $\beta$-glucanase can increase apparent ileal digestibility of DM, CP, GE, AA and other nutrients [12-15]. According to the anti-nutritional factors' binding capacity for trace elements in feedstuffs and reported effects of these enzymes, the release of trace elements in feedstuffs could be promoted by these feed additives. However, few studies have been reported on investigating whether these enzymes could release trace elements from feedstuffs while improving the digestion and utilization efficiency of other nutrients. Thus, this research was conducted to study the effect of different feed enzymes (phytase, xylanase, $\beta$-glucanase) on release rate of trace elements $(\mathrm{Fe}, \mathrm{Cu}, \mathrm{Mn}$ and $\mathrm{Zn}$ ) in 6 commonly used feedstuffs (corn, wheat, barley, soybean meal, wheat bran, wheat middlings) using an in vitro model.

\section{Methods \\ Feedstuffs}

There were six different commonly used feedstuffs (corn, wheat, barley, soybean meal, wheat bran and wheat middlings) and each with 6 batches $(n=6)$. All 36 feedstuff samples were crushed and segregated by 40 mesh sieve.

\section{Determination of trace elements in feedstuffs}

Determination of $\mathrm{Fe}, \mathrm{Cu}, \mathrm{Mn}$ and $\mathrm{Zn}$ content in feedstuffs was done according to the national standard GB/T 13885-2003 [16]. Briefly, measured every element's standard solution, reagent blank and test sample respectively by atomic absorption spectrometer (Thermo Scientific ICE 3300), read the concentration of the elements in the sample according to the standard curve. Measured 3 times for each sample and average. Contents of $\mathrm{Cu}$, $\mathrm{Zn}, \mathrm{Fe}$ and Mn of each sample are listed in Table 1.

\section{Determination of anti-nutritional factors in feedstuffs}

The determination of phytic acid content in feedstuffs was according to the "Standard determination of phytic acid in food" [17]. Xylan and glucan contents in all samples were determined according to the Laboratory Analytical Procedure of "Determination of Structural Carbohydrates and Lignin in Biomass" (Version 2012) from National Renewable Energy Laboratory (NREL) [18]. Contents of anti-nutritional factors of each sample are listed in Table 1.

\section{Digestion of feedstuffs based on the in vitro model}

In vitro digestion was done according to $\mathrm{S}$. Boisen's method $[19,20]$, can be divided into two steps including the simulated stomach and the small intestine digestion.

\section{Simulated stomach digestion}

For each sample, accurately weighed 12 copies of $3.0000 \pm 0.0010 \mathrm{~g}$ finely crushed material into twelve $100 \mathrm{~mL}$ conical flasks. Divided them into 4 different treatment: 1) Phytase group: added $0.3 \mathrm{~mL}$ phosphate buffer $(0.1 \mathrm{~mol} / \mathrm{L}, \mathrm{pH} 6.0)$ containing $300 \mu \mathrm{g}$ phytase $(5,000 \mathrm{U} / \mathrm{g}$, Sun HY) to the sample; 2) Xylanase group: add $0.3 \mathrm{~mL}$ phosphate buffer $(0.1 \mathrm{~mol} / \mathrm{L}, \mathrm{pH} 6.0)$ containing $75 \mu \mathrm{g}$ xylanase $(40,000 \mathrm{U} / \mathrm{g}$, Sun $\mathrm{HY})$ to the sample; 3) $\beta$-glucanase: add $0.3 \mathrm{~mL}$ phosphate buffer $(0.1 \mathrm{~mol} / \mathrm{L}$, $\mathrm{pH}$ 6.0) containing $180 \mu \mathrm{g} \beta$-glucanase $(5,000 \mathrm{U} / \mathrm{g}$, Sun $\mathrm{HY}$ ) to the sample; 4) Control: add $0.3 \mathrm{~mL}$ phosphate buffer $(0.1 \mathrm{~mol} / \mathrm{L}, \mathrm{pH}$ 6.0) without enzyme to the sample. The amount of enzyme added was based on the product specification which meets the actual production requirement. Each flask was added $25 \mathrm{~mL}$ phosphate buffer (0.1 mol/L, pH 6.0) and a magnetic rob and kept magnetic stirring for $1 \mathrm{~min}$, then the $\mathrm{pH}$ of the mixture was adjusted to 2.0 by adding $\mathrm{HCl}(1 \mathrm{~mol} / \mathrm{L})$. After $1 \mathrm{~mL}$ of pepsin solution containing $25 \mathrm{mg}$ pepsin $(3,000 \mathrm{NFU} / \mathrm{mg}$, Ameresco No.0685) and $0.5 \mathrm{~mL}$ chloramphenicol ethanol solution added, digested in the water bath (SHJ - A6) at $39{ }^{\circ} \mathrm{C}$ for $2 \mathrm{~h}$ and stirring slowly and continuously to simulate feed digestion in the stomach.

\section{Simulated small intestine digestion}

After the process of simulated digestion in the stomach, added $10 \mathrm{~mL}$ phosphate buffer $(0.2 \mathrm{~mol} / \mathrm{L}, \mathrm{pH}$ 6.8) and then adjusted $\mathrm{pH}$ to 6.8 by $\mathrm{HCl}(1 \mathrm{~mol} / \mathrm{L})$ or $\mathrm{NaOH}$ $(1 \mathrm{~mol} / \mathrm{L})$. Finally added a magnetic rob and $1 \mathrm{~mL}$ the pancreatin solution containing $50 \mathrm{mg}$ porcine pancreatin ( $\geq 4$ UPS,Sigma No.P-1750) were added into the mixture. Digested for $6 \mathrm{~h}$ in water bath (SHJ - A6) at $39{ }^{\circ} \mathrm{C}$, stirring slowly and constantly to simulate feed digestion in the small intestine.

After digestion, filtrated the digestive production through $0.45 \mu \mathrm{m}$ filter membrane. Supernatant and the residue were collected separately after filtration.

\section{Determination of trace elements in the supernatant}

Put the supernatant in $250 \mathrm{~mL}$ conical flask with plug, added $25 \mathrm{~mL}$ mixed acid (nitric acid: perchloric acid = 4:1, volume ratio), soaked overnight, and then kept heating until the digestive solution became colorless and transparent or slightly yellow. After cooling, diluted the digested product with $1 \%$ nitric acid solution to $50 \mathrm{~mL}$. Determination of trace elements content in the supernatant was done according to the national standard GB/T 13885-2003 [16] as described above.

\section{Determination of anti-nutritional factors in feedstuffs after digestion}

The contents of phytic acid, xylan and $\beta$-glucan in feedstuffs after digestion were determined according to the 
Table 1 The content of $\mathrm{Cu}, \mathrm{Zn}, \mathrm{Fe}, \mathrm{Mn}$ and anti-nutritional factors in feedstuffs

\begin{tabular}{|c|c|c|c|c|c|c|c|c|}
\hline Feedstuffs & Batch & $\mathrm{Cu}, \mathrm{mg} / \mathrm{kg}$ & $\mathrm{Zn}, \mathrm{mg} / \mathrm{kg}$ & $\mathrm{Fe}, \mathrm{mg} / \mathrm{kg}$ & $\mathrm{Mn}, \mathrm{mg} / \mathrm{kg}$ & Phytic acid, g/100 g & Xylan, g/100 g & $\beta$-glucan, $g / 100 \mathrm{~g}$ \\
\hline \multirow[t]{6}{*}{ Corn } & 1 & 3.06 & 15.23 & 67.98 & 20.32 & 1.35 & 6.14 & 0.13 \\
\hline & 2 & 3.11 & 14.98 & 65.65 & 18.98 & 1.15 & 6.20 & 0.18 \\
\hline & 3 & 3.02 & 15.65 & 51.65 & 19.12 & 1.45 & 6.23 & 0.21 \\
\hline & 4 & 3.09 & 15.74 & 69.98 & 16.98 & 1.39 & 6.15 & 0.10 \\
\hline & 5 & 3.04 & 16.57 & 72.92 & 20.16 & 1.27 & 6.27 & 0.14 \\
\hline & 6 & 3.55 & 15.22 & 18.56 & 19.24 & 1.37 & 6.16 & 0.12 \\
\hline \multirow[t]{6}{*}{ Wheat } & 1 & 7.06 & 37.98 & 87.65 & 52.65 & 1.52 & 7.89 & 0.97 \\
\hline & 2 & 7.12 & 40.23 & 90.23 & 49.65 & 1.37 & 8.47 & 0.73 \\
\hline & 3 & 7.03 & 39.98 & 88.98 & 53.65 & 1.48 & 7.29 & 0.68 \\
\hline & 4 & 7.05 & 38.32 & 89.98 & 55.65 & 1.46 & 8.72 & 0.81 \\
\hline & 5 & 7.20 & 30.41 & 86.16 & 48.59 & 1.33 & 7.84 & 0.85 \\
\hline & 6 & 7.31 & 41.54 & 95.64 & 60.43 & 1.41 & 7.93 & 0.82 \\
\hline \multirow[t]{6}{*}{ Barley } & 1 & 6.12 & 32.32 & 62.12 & 36.65 & 1.38 & 5.47 & 4.34 \\
\hline & 2 & 5.98 & 33.32 & 61.98 & 34.32 & 1.74 & 5.69 & 4.19 \\
\hline & 3 & 6.06 & 29.65 & 59.32 & 32.65 & 1.53 & 6.37 & 4.24 \\
\hline & 4 & 9.11 & 31.02 & 60.98 & 35.98 & 1.24 & 5.83 & 4.56 \\
\hline & 5 & 5.56 & 17.85 & 59.01 & 39.69 & 1.62 & 5.15 & 4.16 \\
\hline & 6 & 7.38 & 34.32 & 62.27 & 30.00 & 1.47 & 5.73 & 4.35 \\
\hline \multirow[t]{6}{*}{ Soybean meal } & 1 & 16.65 & 64.65 & 187.65 & 77.65 & 2.57 & 6.20 & 7.12 \\
\hline & 2 & 17.98 & 63.98 & 194.32 & 80.32 & 2.48 & 5.76 & 6.48 \\
\hline & 3 & 18.65 & 61.98 & 188.98 & 74.98 & 2.03 & 5.99 & 6.82 \\
\hline & 4 & 16.98 & 64.65 & 179.98 & 76.98 & 1.96 & 6.14 & 6.73 \\
\hline & 5 & 22.18 & 69.55 & 171.73 & 85.30 & 2.16 & 6.03 & 7.52 \\
\hline & 6 & 15.49 & 43.69 & 122.26 & 53.22 & 2.04 & 5.89 & 6.21 \\
\hline \multirow[t]{6}{*}{ Wheat bran } & 1 & 12.98 & 75.32 & 231.32 & 154.32 & 3.73 & 19.84 & 13.62 \\
\hline & 2 & 13.12 & 73.65 & 209.98 & 159.32 & 3.10 & 19.07 & 14.76 \\
\hline & 3 & 13.06 & 73.49 & 213.32 & 152.32 & 3.27 & 20.73 & 13.79 \\
\hline & 4 & 13.03 & 74.19 & 221.46 & 149.98 & 4.42 & 21.56 & 13.97 \\
\hline & 5 & 13.21 & 75.76 & 209.76 & 160.10 & 3.85 & 18.69 & 14.25 \\
\hline & 6 & 13.64 & 74.59 & 242.48 & 144.18 & 3.77 & 20.48 & 14.00 \\
\hline \multirow[t]{6}{*}{ Wheat middlings } & 1 & 13.12 & 84.98 & 105.32 & 106.65 & 2.41 & 18.05 & 20.01 \\
\hline & 2 & 12.98 & 91.32 & 99.98 & 110.32 & 2.46 & 18.17 & 20.37 \\
\hline & 3 & 12.89 & 82.98 & 112.32 & 102.65 & 2.61 & 17.84 & 19.64 \\
\hline & 4 & 13.09 & 85.65 & 106.65 & 111.45 & 2.32 & 19.47 & 21.58 \\
\hline & 5 & 13.77 & 90.92 & 115.41 & 171.93 & 2.55 & 17.03 & 18.23 \\
\hline & 6 & 10.87 & 68.51 & 100.49 & 102.35 & 2.39 & 17.92 & 19.85 \\
\hline
\end{tabular}

determination of anti-nutritional factors in feedstuffs as described above.

\section{Data calculation}

The release rate of trace elements in feedstuffs were calculated by the following formula:
Release rate $(\%)=C_{s} / C_{T} \times 100 \%$,

where $C_{s}$ is the soluble trace element content which calculated by measured value in the supernatant and $C_{T}$ is the corresponding total trace element content.

The hydrolysis rate of anti-nutritional factors were calculated by the following formula:

Hydrolysis rate $(\%)=100 \%-A_{D} / A_{F} \times 100 \%$, 
where $A_{D}$ is the and $A_{F}$ is the anti-nutritional factors content after digestion, $A_{F}$ is the corresponding anti-nutritional factors in feedstuffs .

\section{Statistical analysis}

The release rate of trace elements and the content of anti-nutritional factors in the feedstuffs after digestion in the feedstuffs after digestion are presented as mean \pm standard deviation (SD). Means between groups were compared by one-way analysis of variance and Scheffe's post-hoc test or non-parameter Kruskal-Wallis test (SPSS software, version 21). $P<0.05$ was considered significant.

\section{Results}

The release rate of trace elements in corn

The release rate of trace elements after enzyme treatment in corn are shown in Table 2. The release rate of $\mathrm{Cu}$ in the phytase group, the xylanase group and the $\beta$-glucanase group was $50.94 \%, 28.97 \%$ and $30.92 \%$ higher, respectively than in the control group $(P<0.05)$. The release rate of $\mathrm{Zn}$ in phytase and xylanase groups were higher than the control group $(P<0.05)$. Xylanase and $\beta$-glucanase raised the release rate of $\mathrm{Mn}$.

\section{The release rate of trace elements in wheat}

The release rate of trace elements in wheat treated by enzyme preparations are shown in Table 3 . The three enzyme preparations had a significant effect on the release of $\mathrm{Cu}$ in wheat $(P<0.05)$ and phytase and xylanase increased the release rate of $\mathrm{Zn}$ and $\mathrm{Mn}(P<0.05)$.

\section{The release rate of trace elements in barley}

As can be seen from Table 4, the release rate of $\mathrm{Cu}$ in the phytase group and the xylanase group increased by $11.57 \%$ and $11.96 \%$ respectively $(P<0.05)$ compared with the control group. Treatment with $\beta$-glucanase increased the release rate of $\mathrm{Fe}(P<0.05)$ and xylanase promote the release of $\mathrm{Mn}$ in barley $(P<0.05)$.

\section{The release rate of trace elements in soybean meal}

Table 5 presents the release rate of trace elements in enzyme-treated soybean meal. The release rate of $\mathrm{Cu}$ in the phytase group and xylanase group were significantly higher than in the control group $(P<0.05)$, while Fe

Table $\mathbf{2}$ The release rate of trace elements in corn

\begin{tabular}{lllll}
\hline \multirow{2}{*}{$\begin{array}{l}\text { Trace } \\
\text { elements }\end{array}$} & Control group & \multicolumn{4}{l}{ Enzyme preparation } \\
\cline { 3 - 5 } & & Phytase & Xylanase & $\beta$-glucanase \\
\hline $\mathrm{Cu}, \%$ & $40.09 \pm 11.95^{\mathrm{c}}$ & $91.03 \pm 4.61^{\mathrm{a}}$ & $69.06 \pm 6.88^{\mathrm{b}}$ & $71.01 \pm 8.79^{\mathrm{b}}$ \\
$\mathrm{Zn}, \%$ & $60.09 \pm 3.39^{\mathrm{b}}$ & $90.42 \pm 5.96^{\mathrm{a}}$ & $90.63 \pm 8.84^{\mathrm{a}}$ & $64.78 \pm 6.19^{\mathrm{b}}$ \\
$\mathrm{Fe}, \%$ & $43.95 \pm 8.19$ & $53.70 \pm 2.92$ & $50.58 \pm 7.88$ & $55.31 \pm 5.15$ \\
$\mathrm{Mn}, \%$ & $13.12 \pm 3.23^{\mathrm{c}}$ & $17.67 \pm 1.98^{\mathrm{c}}$ & $30.35 \pm 2.53^{\mathrm{b}}$ & $68.52 \pm 4.70^{\mathrm{a}}$ \\
\hline $\mathrm{a}, \mathrm{b}, \mathrm{c}$ Means values within a row not sharing a common letter differ significantly $(P<0.05)$
\end{tabular}

Table 3 The release rate of trace elements in wheat

\begin{tabular}{lllll}
\hline Trace & Control & \multicolumn{4}{l}{ Enzyme preparation } \\
\cline { 3 - 5 } elements & group & Phytase & Xylanase & $\beta$-glucanase \\
\hline $\mathrm{Cu}, \%$ & $19.61 \pm 1.92^{\mathrm{d}}$ & $52.99 \pm 3.99^{\mathrm{b}}$ & $64.88 \pm 3.32^{\mathrm{a}}$ & $32.02 \pm 4.62^{\mathrm{c}}$ \\
$\mathrm{Zn}, \%$ & $7.48 \pm 1.66^{\mathrm{b}}$ & $30.62 \pm 2.59^{\mathrm{a}}$ & $33.66 \pm 4.14^{\mathrm{a}}$ & $11.38 \pm 2.79^{\mathrm{b}}$ \\
$\mathrm{Fe}, \%$ & $10.90 \pm 0.49^{\mathrm{c}}$ & $36.49 \pm 3.17^{\mathrm{b}}$ & $50.42 \pm 2.24^{\mathrm{a}}$ & $11.52 \pm 0.41^{\mathrm{c}}$ \\
$\mathrm{Mn}, \%$ & $20.68 \pm 4.16^{\mathrm{b}}$ & $46.35 \pm 2.47^{\mathrm{a}}$ & $43.32 \pm 4.38^{\mathrm{a}}$ & $14.99 \pm 3.27^{\mathrm{b}}$
\end{tabular}

$\overline{a, b, c, d}$ Means values within a row not sharing a common letter differ significantly $(P<0.05)$

release rate was higher in the $\beta$-glucanase group. Phytase raised the release rate of $\mathrm{Zn}$ and $\mathrm{Mn}(P<0.05)$.

The release rate of trace elements in wheat bran

As shown in Table 6, all enzyme preparations could significantly increase the release rate of $\mathrm{Mn}(P<0.05)$. Compared with the control group, the release rate of $\mathrm{Fe}$ in phytase group and $\beta$-glucanase group increased by $11.33 \%$ and $6.72 \%$ respectively $(P<0.05)$, the release rate of $\mathrm{Zn}$ in phytase group increased by $48.82 \%(P<0.05)$ and the release rate of $\mathrm{Cu}$ in $\beta$-glucanase group increased by $57.00 \%(P<0.05)$.

\section{The release rate of trace elements in wheat middlings}

The release rate in wheat middlings after being treated by enzyme preparations are listed in Table 7 . Compared with the control group, xylanase raised the release rate of $\mathrm{Zn}(P<0.05)$ and phytase raised the release rate of $\mathrm{Zn}, \mathrm{Fe}$ and $\mathrm{Mn}(P<0.05)$.

\section{The digestion of anti-nutritional factors in feedstuffs}

Figure 1 presents the digestion of anti-nutritional factors in feedstuffs. Figure 1a-c present the contents of phytic acid, xylan and $\beta$-glucan in feedstuffs after digestion respectively and Fig. 1d presents the hydrolysis rate of anti-nutritional factors after corresponding enzyme treatment. In each feedstuff, after corresponding enzyme treatment, the contents of phytic acid, xylan and $\beta$-glucan were significantly lower than those of the control group $(P<0.05)$. In corn, wheat, barley, soybean meal, wheat bran and wheat middlings, the phytic acid content of the phytase group was $58.41 \%, 66.42 \%$, $58.88 \%, 64.20 \%, 49.52 \%$ and $52.23 \%$ lower than that the control group, respectively $(P<0.05)$. Compared with

Table 4 The release rate of trace elements in barley

\begin{tabular}{lllll}
\hline Trace & Control & \multicolumn{4}{l}{ Enzyme preparation } \\
\cline { 3 - 5 } elements & group & Phytase & Xylanase & $\beta$-glucanase \\
\hline $\mathrm{Cu}, \%$ & $25.85 \pm 3.84^{\mathrm{b}}$ & $37.42 \pm 7.59^{\mathrm{a}}$ & $37.81 \pm 4.53^{\mathrm{a}}$ & $30.19 \pm 3.31^{\mathrm{ab}}$ \\
$\mathrm{Zn}, \%$ & $11.91 \pm 1.86$ & $20.18 \pm 2.18$ & $20.71 \pm 3.12$ & $18.99 \pm 2.68$ \\
$\mathrm{Fe}, \%$ & $31.05 \pm 1.56^{\mathrm{b}}$ & $32.45 \pm 2.27^{\mathrm{ab}}$ & $33.14 \pm 2.00^{\mathrm{ab}}$ & $41.38 \pm 4.98^{\mathrm{a}}$ \\
$\mathrm{Mn}, \%$ & $42.26 \pm 5.22^{\mathrm{b}}$ & $47.45 \pm 2.30^{\mathrm{ab}}$ & $54.70 \pm 6.54^{\mathrm{a}}$ & $50.00 \pm 4.60^{\mathrm{ab}}$ \\
\hline
\end{tabular}

$\overline{\mathrm{a}, \mathrm{b}}$ Means values within a row not sharing a common letter differ significantly $(P<0.05)$ 
Table $\mathbf{5}$ The release rate of trace elements in soybean meal

\begin{tabular}{lllll}
\hline Trace & \multirow{2}{*}{$\begin{array}{l}\text { Control } \\
\text { elements }\end{array}$} & group & \multicolumn{4}{l}{ Enzyme preparation } \\
\cline { 3 - 5 } & & Phytase & Xylanase & $\beta$-glucanase \\
\hline $\mathrm{Cu}, \%$ & $60.60 \pm 5.79^{\mathrm{c}}$ & $85.91 \pm 8.25^{\mathrm{ab}}$ & $91.06 \pm 6.05^{\mathrm{a}}$ & $74.08 \pm 7.07^{\mathrm{bc}}$ \\
$\mathrm{Zn}, \%$ & $53.75 \pm 7.34^{\mathrm{b}}$ & $65.00 \pm 3.42^{\mathrm{a}}$ & $60.81 \pm 4.49^{\mathrm{b}}$ & $56.19 \pm 4.95^{\mathrm{b}}$ \\
$\mathrm{Fe}, \%$ & $27.37 \pm 2.48^{\mathrm{b}}$ & $32.45 \pm 2.27^{\mathrm{ab}}$ & $31.61 \pm 1.61^{\mathrm{b}}$ & $33.23 \pm 4.06^{\mathrm{a}}$ \\
$\mathrm{Mn}, \%$ & $15.57 \pm 1.68^{\mathrm{b}}$ & $21.07 \pm 0.94^{\mathrm{a}}$ & $16.73 \pm 1.14^{\mathrm{b}}$ & $17.34 \pm 1.90^{\mathrm{b}}$
\end{tabular}

$\overline{\mathrm{a}, \mathrm{b}, \mathrm{c}}$ Means values within a row not sharing a common letter differ significantly $(P<0.05)$

the control group, treatment with xylanase reduced the xylan content in corn, wheat, barley, soybean meal, wheat bran and wheat middlings by $61.99 \%, 51.45 \%, 59.75 \%$, $58.24 \%, 49.93 \%$ and $50.15 \%$, respectively. The $\beta$-glucan content of the $\beta$-glucanase group in these feedstuffs decreased by $60.61 \%, 46.18 \%, 57.18 \%, 48.79 \%, 45.05 \%$ and $42.39 \%$ respectively compared with the control group. The hydrolysis rate of phytic acid in corn, wheat, barley, soybean meal, wheat bran and wheat middlings is $62.93 \%, 76.45 \%, 67.05 \%$, $70.26 \%, 61.92 \%$ and $61.35 \%$, respectively, xylan is $65.07 \%$, $59.60 \%, 63.21 \%, 61.80 \%, 56.07 \%$ and $55.50 \%$, respectively, and $\beta$-glucan is $65.22 \%, 53.07 \%, 62.53 \%, 50.89 \%, 50.80 \%$ and $49.18 \%$, respectively.

\section{Discussion}

Plant-based feedstuffs contain various kinds of anti-nutritional factors such as phytic acid, xylan, $\beta$-glucan, which affect the digestive utilization of nutrients for livestocks. The amount of anti-nutritional factors differs among feedstuffs $[5,6]$.

Phytic acid, commonly called phytate, also known as inositol hexaphosphate (IP6). It is a strong chelator, which can chelating divalent and trivalent metal ions to form insoluble precipitate, thereby affecting the absorption of these elements. Several reports confirmed that phytase hydrolyze phytate and then release trace elements like $\mathrm{Cu}$ and $\mathrm{Fe}$, making them more available to animals. Shelton et al. [21] reported that digestive utilization of $\mathrm{Zn}, \mathrm{Fe}$ and $\mathrm{Mn}$ in pigs have been improved after supplementing diets with phytase. Revy et al. [22] had compared the bioavailability of $\mathrm{Zn}$ when piglets were fed with three different diets, basic rations $(32 \mathrm{mg} /$ $\mathrm{kg} \mathrm{Zn}$ ) with $20 \mathrm{mg} / \mathrm{kg}$ organic zinc, or inorganic zinc or $1,200 \mathrm{U} / \mathrm{kg}$ phytase and showed that phytase greatly

Table $\mathbf{6}$ The release rate of trace elements in wheat bran

\begin{tabular}{lllll}
\hline $\begin{array}{l}\text { Trace } \\
\text { elements }\end{array}$ & Control & \multicolumn{4}{l}{ Enzyme preparation } \\
\cline { 3 - 5 } & & Phytase & Xylanase & $\beta$-glucanase \\
\hline $\mathrm{Cu}, \%$ & $19.10 \pm 1.34^{\mathrm{b}}$ & $56.35 \pm 4.13^{\mathrm{ab}}$ & $46.15 \pm 1.75^{\mathrm{bc}}$ & $67.92 \pm 5.54^{\mathrm{a}}$ \\
$\mathrm{Zn}, \%$ & $5.29 \pm 0.70^{\mathrm{b}}$ & $62.29 \pm 3.63^{\mathrm{a}}$ & $33.65 \pm 2.33^{\mathrm{ab}}$ & $12.09 \pm 0.83^{\mathrm{ab}}$ \\
$\mathrm{Fe}, \%$ & $11.33 \pm 1.51^{\mathrm{b}}$ & $21.66 \pm 2.55^{\mathrm{a}}$ & $13.19 \pm 2.02^{\mathrm{b}}$ & $18.05 \pm 0.54^{\mathrm{a}}$ \\
$\mathrm{Mn}, \%$ & $6.83 \pm 1.11^{\mathrm{c}}$ & $28.74 \pm 1.80^{\mathrm{a}}$ & $13.97 \pm 1.57^{\mathrm{b}}$ & $14.98 \pm 1.60^{\mathrm{b}}$ \\
\hline $\mathrm{a}, \mathrm{b}, \mathrm{c}$ Means values within a row not sharing a common letter differ significantly $(\boldsymbol{P}<0.05)$
\end{tabular}

Table $\mathbf{7}$ The release rate of trace elements in wheat middlings

\begin{tabular}{lllll}
\hline Trace & Control & \multicolumn{4}{l}{ Enzyme preparation } \\
\cline { 3 - 5 } elements & group & Phytase & Xylanase & $\beta$-glucanase \\
\hline $\mathrm{Cu}, \%$ & $33.77 \pm 1.44$ & $35.69 \pm 4.45$ & $35.73 \pm 2.10$ & $38.83 \pm 3.36$ \\
$\mathrm{Zn}, \%$ & $11.48 \pm 1.42^{\mathrm{c}}$ & $24.11 \pm 3.08^{\mathrm{a}}$ & $16.98 \pm 1.67^{\mathrm{b}}$ & $12.57 \pm 0.68^{\mathrm{c}}$ \\
$\mathrm{Fe}, \%$ & $29.66 \pm 1.36^{\mathrm{b}}$ & $34.28 \pm 3.09^{\mathrm{a}}$ & $33.12 \pm 2.06^{\mathrm{b}}$ & $31.73 \pm 2.27^{\mathrm{b}}$ \\
$\mathrm{Mn}, \%$ & $20.64 \pm 0.92^{\mathrm{b}}$ & $29.87 \pm 1.73^{\mathrm{a}}$ & $20.80 \pm 1.52^{\mathrm{b}}$ & $19.07 \pm 1.60^{\mathrm{b}}$ \\
\hline
\end{tabular}

$\overline{\mathrm{a}, \mathrm{b}, \mathrm{c}}$ Means values within a row not sharing a common letter differ significantly $(P<0.05)$

improved the intestinal bioavailability of $\mathrm{Zn}$ and promote effective utilization of $\mathrm{Ca}, \mathrm{P}, \mathrm{Mg}$, Fe and $\mathrm{Cu}$. In another study [23], it was reported that phytase supplementation of diet increased $\mathrm{Zn}$ and $\mathrm{Cu}$ bioavailability significantly. Kim et al. [24] found that use of phytase can significantly improve the iron status of piglets and thus reduce adverse performance due to iron deficiency. The results of previous in vivo studies are consistent with the present in vitro one, where phytase greatly raised the release rate of $\mathrm{Cu}$ and $\mathrm{Zn}$ in corn, $\mathrm{Cu}$, $\mathrm{Zn}$ and $\mathrm{Mn}$ in wheat, $\mathrm{Cu}$ in barley, $\mathrm{Cu}, \mathrm{Zn}$ and $\mathrm{Mn}$ in soybean meal, Zn, Fe in wheat bran, Zn, Fe, Mn in wheat middlings. These results implied that phytic acid can not only inhibit the absorption of $\mathrm{Ca}$ and $\mathrm{P}$, but also made it hard for monogastric livestock to absorb trace elements. The results of our research also suggested that phytic acid binds more strongly to $\mathrm{Cu}$ and $\mathrm{Zn}$ in these feedstuffs. According to the results of the digestion of phytic acid in feedstuffs (Fig. 1a and Fig. 1d) and the results above, it can be speculated that the digestion of phytic acid promotes the release of trace elements in feedstuffs. Therefore, phytic acid may be one of the main anti-nutritional factors which affect the release of trace elements in these feedstuffs.

Xylan is also called the Arab xylan, mainly consisted of Arab sugar and xylose [25]. Xylan constitutes most of cell wall NSP in corn, wheat and barley. Researches showed that the utilization rate of nutrients will be lower when livestocks are fed with excessive feedstuffs containing much xylan such as corn, wheat, barley, bran and so on, which resulted from the anti-nutritional effect of xylan that played the role by improving livestocks' intestinal chyme viscosity, slowing down the movement speed of chyme in the digestive tract and changing the morphology of digestive tract [26-28]. In addition, as one of the NSP, xylan could easily form complexes with minerals by electrostatic interactions. It will be deprotonated at around neutral $\mathrm{pH}$, and therefore ions like $\mathrm{Ca}^{2+}$, $\mathrm{Fe}^{2+}$ and $\mathrm{Zn}^{2+}$ will interact with the negative charged groups [29]. Xylanase supplementation of diets has been reported to improve the nutrient digestibility such as GE, AA, P, and Ca [30-33]. There is also an in vitro study showing that adding xylanase can release chelated zinc and iron in pearl millet grain [7].Our data showed that the 


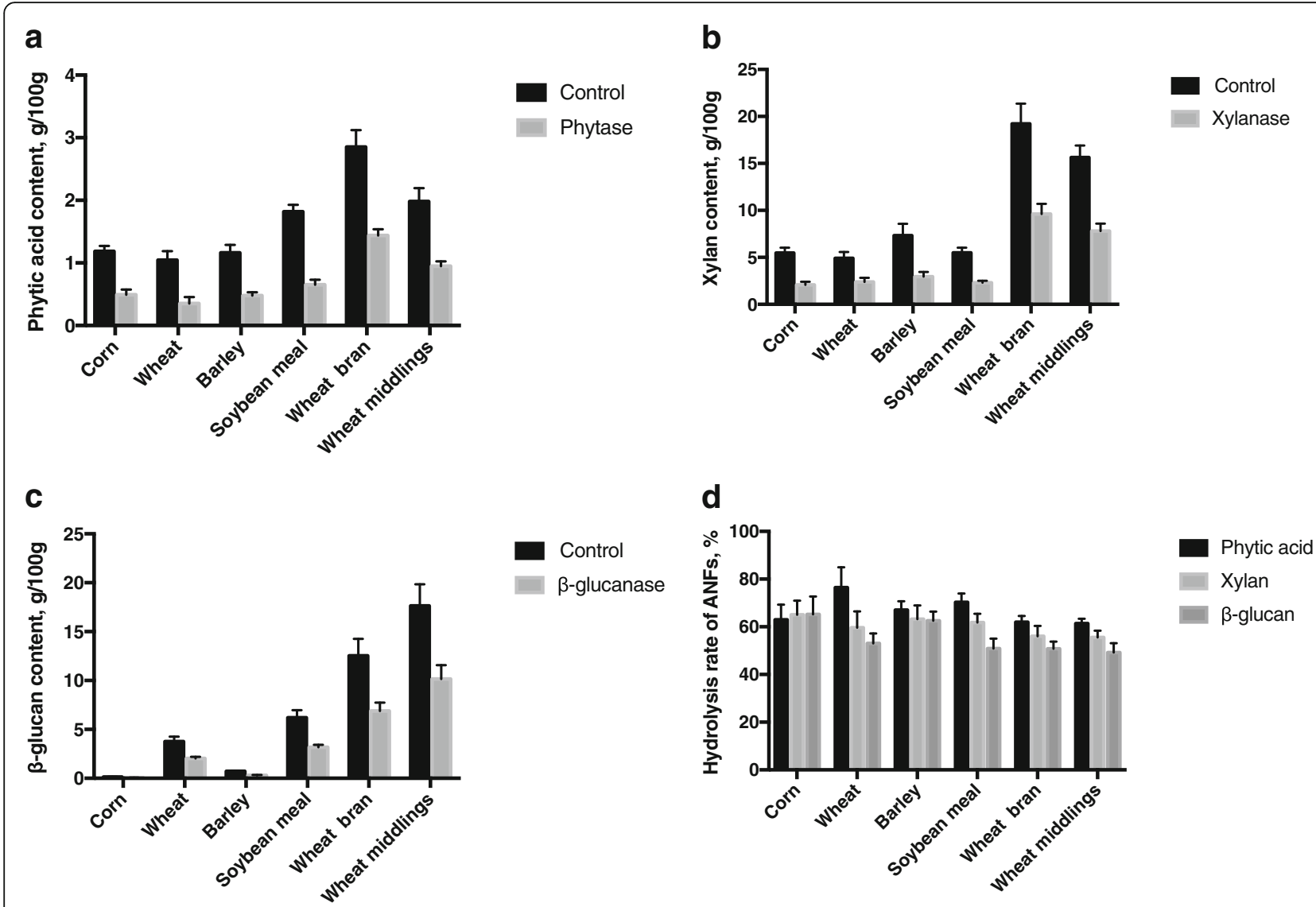

Fig. 1 The digestion of anti-nutritional factors in feedstuffs. Values are means $\pm S D(n=6)$. $\mathbf{a}, \mathbf{b}$ and $\mathbf{c}$ present the phytic acid, xylan and $\beta$-glucan contents in feedstuffs after digestion respectively, $\mathbf{d}$ presents the hydrolysis rate of anti-nutritional factors after corresponding enzyme treatment. In each feedstuff, after corresponding enzyme treatment, the contents of phytic acid, xylan and $\beta$-glucan were significantly lower than those of the control group $(P<0.05)$

release rate of various trace elements in feedstuffs had been increased after xylanase addition. Compared with the control group, after xylanase treatment, the release rate of $\mathrm{Cu}$ in corn, wheat, barley and soybean meal, the release rate of $\mathrm{Zn}$ in corn, wheat and wheat middlings and the release rate of $\mathrm{Mn}$ in corn, wheat, barley and wheat bran all increased significantly $(P<0.05)$. These findings suggest that xylan is one of the main anti-nutritional factors to bind $\mathrm{Cu}, \mathrm{Zn}$ and $\mathrm{Mn}$ in cereal feed and its byproducts. Besides, xylanase performs better in increasing the release rate of trace elements in corn, wheat and barley. Based on our study on the digestion of xylan in feedstuffs (Fig. 1b and Fig. 1d), xylanase performs well on xylan digestibility in corn, wheat and barley. It could be inferred from the results above that xylan mainly affect the release of $\mathrm{Cu}, \mathrm{Zn}$ and $\mathrm{Mn}$ in corn, wheat and barley.

$\beta$-glucan, like xylan, is also a member of NSP. It is present in most cereals and is particularly prevalent in barley and oats. $\beta$-glucan consists of a linear chain of glucose monomers linked by $\beta-1-3$ and $\beta-1-4$ linkages in different ratios [34, 35]. The effects of $\beta$-glucan on the absorption of nutrients for livestocks is mainly through the following four aspects: 1) $\beta$-glucan encrusting the cell wall and can bind the nutrients in the cell. 2) Its hydrophilicity cause the increase of water layer's thickness on the intestinal mucosal surface. 3) Due to the presence of $\beta-1-3$ linkages, the microfibrils in $\beta$-glucan are more tightly packed together, giving them higher solubility than cellulose. Its solubility and considerable length can easily lead to the increase of intestinal viscosity, thus decrease the diffusion rate of enzyme and nutrients and impede well mix of them. 4) It increases chyme viscosity, slow down their movement, thus produce harmful microorganisms and acidic substance which greatly reduce enzymes' effects [27, 36-38]. In addition, similar to the effect of xylan on electrostatic interactions, it can interact electrostatically with ions like $\mathrm{Ca}^{2+}, \mathrm{Fe}^{2+}$, $\mathrm{Zn}^{2+}$ to lower the efficiency of utilization. $\beta$-glucanase can crack $\beta$-glucan into small molecule and force $\beta$-glucan to lose hydrophilicity and thus reduce the viscosity of intestinal contents to improve absorption of nutrition in livestocks. Besides, $\beta$-glucanase will release 
intracellular nutrition by degrading the cell wall. In this study, after the treatment of $\beta$-glucanase, the release rate of soluble $\mathrm{Cu}$ in corn, wheat and wheat bran, the release rate of $\mathrm{Fe}$ in barley, soybean meal and wheat bran, the release rate of $\mathrm{Mn}$ in corn and wheat bran all increased significantly compared with the control group $(P<0.05)$. The results showed that $\beta$-glucan affect the release of $\mathrm{Cu}, \mathrm{Fe}$ and $\mathrm{Mn}$ in these feedstuffs. Our data also indicated that $\beta$-glucanase had better impact on the release of trace elements in corn and wheat bran. After $\beta$-glucanase treatment, compared with the control group, the digestion of $\beta$-glucan of the $\beta$-glucanase group increased in all these feedstuffs $(P<0.05)$. According to the results above, we may infer that $\beta$-glucan mainly affect the release of trace elements in corn and wheat bran.

\section{Conclusion}

Anti-nutritional factors like phytate, xylan and $\beta$-glucan could inhibit digestion and absorption of trace elements, corresponding enzyme treatment could digest the anti-nutritional factors in conventional feedstuffs and thus release a certain amount of trace elements. Phytase performs better on the release of $\mathrm{Cu}$ and $\mathrm{Zn}$ in feedstuffs, xylanase has good effect on releasing $\mathrm{Cu}, \mathrm{Zn}$ and $\mathrm{Mn}$ in cereal feed, $\beta$-glucanase improve the release rate of $\mathrm{Cu}, \mathrm{Fe}$ and $\mathrm{Mn}$ and it performs better on corn and wheat bran.

\section{Abbreviations}

AA: Amino acid; ANFs: Anti-nutritional factors; CP: Crude protein; DM: Dry matter; GE: Gross energy; NSP: Non-starch polysaccharide

\section{Acknowledgements}

We are grateful to Linjun Chen, Haoxuan Ding and Guohua Wang for the assistance with the digestion process, to Bojing Liu and Xinyang Dong for assistance with the measurement of trace elements and anti-nutritional factors. Moreover, we thank ZheJiang Kesheng Feed Stock Co., LTD for providing the feedstuffs.

\section{Funding}

This research was financially supported by the National Key R\&D Program of China (No. 2016YFD0501201), National Natural Sciences Foundation of China (No. 31472102, No.31772607), and Zhejiang Provincial Key Science Project (No. 2015C03006)

\section{Availability of data and materials}

The datasets generated and/or analysed during the current study are available from the corresponding author on reasonable request.

\section{Authors' contributions \\ JF designed the research. XY, JH, HL and YZ collected data and samples. XY, $\mathrm{JH}$ and $\mathrm{HL}$ prepared the reagent and conducted the feedstuffs digestion. $\mathrm{XY}$, $\mathrm{JH}$ and $\mathrm{HL}$ measured the contents of race elements and anti-nutritional factors. XY analyzed data and wrote the original draft. JF reviewed and edited the paper. All authors read and approved the final manuscript.}

Ethics approval and consent to participate

Not applicable.

\section{Consent for publication}

Not applicable.

\section{Competing interests}

The authors declare that they have no competing interests.
Received: 24 May 2018 Accepted: 23 August 2018

Published online: 15 October 2018

\section{References}

1. Hostetler CE, Kincaid RL, Mirando MA. The role of essential trace elements in embryonic and fetal development in livestock. Vet J. 2003;166:125-39.

2. Cang L, Wang YJ, Zhou DM, Dong YH. Heavy metal pollution in poultry and livestock feeds and manures under intensive farming in Jiangsu Province. China J Environ Sci. 2004;03:371-4.

3. Li Y, Chen T. Concentrations of additive arsenic in Beijing pig feeds and the residues in pig manure. Resour Conserv Recy. 2005;45:356-67.

4. Chary NS, Kamala CT, Raj DSS. Assessing risk of heavy metals from consuming food grown on sewage irrigated soils and food chain transfer. Ecotox Environ Safe. 2008;69:513-24.

5. Elke H, Karl S. Fermentation of food and feed: a technology for efficient utilization of macro and trace elements in monogastrics. J Trace Elem Med Bio. 2016;37:69-77.

6. Raes K, Knockaert D, Struijs K, Van CJ. Role of processing on bioaccessibility of minerals: influence of localization of minerals and antinutritional factors in the plant. Trends Food Sci Tech. 2014:37:32-41.

7. Lestienne I, Caporiccio B, Besançon P, Rochette I, Trèche S. Relative contribution of phytates, fibers, and tannins to low iron and zinc in vitro solubility in pearl millet (Pennisetum glaucum) flour and grain fractions. J Agric Food Chem. 2005;21:8342-8.

8. Tiwari SP, Gendley MK, Pathak AK, Gupta R. Influence of an enzyme cocktail and phytase individually or in combination in Ven cobb broiler chickens. Brit Poult Sci. 2010;51:92-100.

9. Selle PH, Ravindran V. Microbial phytase in poultry nutrition. Anim Feed Sci Tech. 2007;135:1-41.

10. Gonzálezvega JC, Walk CL, Stein HH. Effects of microbial phytase on apparent and standardized total tract digestibility of calcium in calcium supplements fed to growing pigs. J Anim Sci. 2015;93:2255-64.

11. Letourneau-Montminy MP, Jondreville C, Sauvant D, Narcy A. Meta- analysis of phosphorus utilization by growing pigs: effect of dietary phosphorus, calcium and exogenous phytase. Animal. 2012;6:1590-600.

12. Owusu-Asiedu A, Kiarie E, Peron A, Woyengo TA, Simmins PH, Nyachoti CM. Growth performance and nutrient digestibilities in nursery pigs receiving varying doses of xylanase and beta-glucanase blend in pelleted wheat-and barley-based diets. J Anim Sci. 2012;90:92-4.

13. Kerr BJ, Shurson GC. Strategies to improve fiber utilization in swine. J Anim Sci Biotechnol. 2013:4:11-23.

14. Clarke LC, Sweeney T, Curley E, Gath V, Duffy SK, Vigors S, et al. Effect of $\beta$ glucanase and $\beta$-xylanase enzyme supplemented barley diets on nutrient digestibility, growth performance and expression of intestinal nutrient transporter genes in finisher pigs. Anim Feed Sci Tech. 2018;238:98-110.

15. Yin YL, Baidoo SK, Jin LZ, Liu YG, Schulze H, Simmins PH. The effect of different carbohydrase and protease supplementation on apparent (ileal and overall) digestibility of nutrients of five hulless barley varieties in young pigs. Livest Prod Sci. 2001;71:109-20.

16. GB/T 13885-2003/ISO 6869:2000, Animal feeding stuffs-Determination of the contents of calcium, copper, Iron, magnesium, manganese, potassium, sodium and zinc-Method using atomic absorption spectrometry(In Chinese).

17. GB 5009.153-2016. Standard determination of phytic acid in food(In Chinese).

18. Sluiter A, Hames B, Ruiz R, Scarlata C, Sluiter J, Templeton D, Crocker D. Determination of Structural Carbohydrates and Lignin in Biomass. In: Laboratory analytical procedure. National Renewable Laboratory, NREL/ TP510-42618, USA; 2012

19. Boisen S, Fernandez JA. Prediction of the apparent ileal digestibility of protein and amino acids in feedstuffs and feed mixtures for pigs by in vitro analyses. Anim Feed Sci Tech. 1995;51:29-43.

20. Boisen S, Fernandez JA. Prediction of the total tract digestibility of energy in feedstuffs and pig diets by in vitro analyses. Anim Feed Sci Tech. 1997;68: 277-86.

21. Shelton JL, LeMieux FM, Southern LL, Bidner TD. Effect of microbial phytase addition with or without the trace mineral premix in nursery, growing. and finishing pig diets J Anim Sci. 2005;83:376-85.

22. Revy PS, Jondreville C, Dourmad JY, Nys Y. Effect of zinc supplemented as either an organic or an inorganic source and of microbial phytase on zinc and other minerals utilisation by weanling pigs. Anim Feed Sci Tech. 2004; 16:93-112. 
23. Adebiyi OA, Ologhobo AD, Agboola AS. Effects of microbial phytase supplementation on mineral composition of tibia and mineral utilization in broiler fed maize-based diets. Int J Poult Sci. 2009;8:570-3.

24. Kim JC, Wilcock P, Bedford MR. Iron status of piglets and impact of phytase superdosing on iron physiology: a review. Anim Feed Sci Tech. 2018;235:8-14.

25. Saulnier L, Guillon F, Chateigner-Boutin AL. Cell wall deposition and metabolism in wheat grain. J Cereal Sci. 2012;56:91-108.

26. Jaworski NW, Lærke HN, Bach Knudsen KE, Stein HH. Carbohydrate composition and in vitro digestibility of dry matter and nonstarch polysaccharides in corn, sorghum, and wheat and coproducts from these grains. J Anim Sci. 2015;93:1103-13.

27. Bedford MR. Mechanism of action and potential environmental benefits from the use of feed enzymes. Anim Feed Sci Tech. 1995;53:145-55.

28. Gutierrez NA, Serão NVL, Kerr BJ, Zijistra RT, Patience JF. Relationships among dietary fiber components and the digestibility of energy, dietary fiber, and amino acids and energy content of nine corn coproducts fed to growing pigs. J Anim Sci. 2014;92:4505-17.

29. Debon SJ, Tester RF. In vitro binding of calcium, iron and zinc by nonstarch polysaccharides. Food Chem. 2001;73:401-10.

30. Diebold G, Mosenthin R, Piepho HP, Sauer WC. Effect of supplementation of xylanase and phospholipase to a wheat-based diet for weanling pigs on nutrient digestibility and concentrations of microbial metabolites in ileal digesta and feces. J Anim Sci. 2004;82:2647-56.

31. Pedersen MB, Yu S, Arent S, Dalsgaard S, Bach Knudsen KE, Lærke HN. Xylanase increased the ileal digestibility of nonstarch polysaccharides and concentration of low molecular weight nondigestible carbohydrates in pigs fed high levels of wheat distillers dried grains with solubles. J Anim Sci. 2015;93:2885-93.

32. Nortey TN, Patience JF, Sands JS, Trottier NL, Zijlstra RT. Effects of xylanase supplementation on the apparent digestibility and digestible content of energy, amino acids, phosphorus, and calcium in wheat and wheat byproducts from dry milling fed to grower pigs. J Anim Sci. 2008;86:3450-64.

33. Woyengo TA, Sands JS, Guenter W, Nyachoti CM. Nutrient digestibility and performance responses of growing pigs fed phytase-and xylanasesupplemented wheat-based diets. J Anim Sci. 2008;86:848-57.

34. Fry SC, Nesselrode BHWA, Miller JG, Mewburn BR. Mixed-linkage (1-3,1-4)- $\beta$ d-glucan is a major hemicellulose of Equisetum (horsetail) cell walls. New Phytol. 2008;179:104-15.

35. Sørensen I, Pettolino FA, Wilson SM, Doblin MS, Johansen B, Bacic A, Willats WGT. Mixed-linkage $(1,3 ; 1,4)-\beta$-D-glucan is not unique to the poales and is an abundant component of Equisetum arvense cell walls. Plant J. 2008;54:510-21.

36. Burton RA, Fincher GB. $(1,3: 1,4)-\beta$-D-glucans in cell walls of the poaceae, lower plants and funghi: a tale of two linkages. Mol Plant. 2009;2:873-82.

37. Masey O'Neill HV, Smith JA, Bedford MR. Multicarbohydrase enzymes for non-ruminants. Asian-Australas J Anim Sci. 2014;27:290-301.

38. Wang L, Newman RK, Newman CW, Hofer PJ. Barley beta-glucans alter intestinal viscosity and reduce plasma cholesterol concentrations in chicks. J Nutr. 1992;122:2292-7.

Ready to submit your research? Choose BMC and benefit from:

- fast, convenient online submission

- thorough peer review by experienced researchers in your field

- rapid publication on acceptance

- support for research data, including large and complex data types

- gold Open Access which fosters wider collaboration and increased citations

- maximum visibility for your research: over $100 \mathrm{M}$ website views per year

At BMC, research is always in progress.

Learn more biomedcentral.com/submissions 